\title{
BMW GROUP ECONOMIC POSITION ANALYSIS IN THE SITUATION CREATED BY COVID-19 PANDEMIC
}

\author{
https://doi.org/10.47743/jopafl-2021-20-11
}

\author{
Ionel - Gabriel DOBRIN \\ Drăgan European University Lugoj, \\ Lugoj, România \\ gabriel.dobrin@deu.ro
}

\begin{abstract}
In 2020, the coronavirus crisis caused the global economy to slump on a scale not seen since the Great Depression in the 1930s. Thus, the International Monetary Fund (IMF) estimates the contraction in global gross domestic product of 3.5\%. Europe's economy too was hit strongly by the pandemic crisis, the eurozone contracted by $7.6 \%$ compared to the previous year. Significant losses were recorded in Germany (-5.0\%), France (-8.3\%), Italy (-9.0\%), Spain (-11.0\%). Several sectors of the economy were completely paralised at times due to lockdowns lasting long periods of time; within this difficult context automotive industry was not spared by the problems generated by the pandemic context.

Keywords: pandemic, forecasts, results of operation, incomes, costs, sales, assets, equity, liabilities.
\end{abstract}

\section{Short global approach of the economic context created by the pandemic}

Unemployment rates registered important increases in most of the states, despite the increases being at least partially held down by short-time work programmes.

Governments of these states implemented extensive economic stimulus packages in order to support their own economies. The assistance programmes caused government spending to rise sharply in 2020, resulting in higher debt ratios. In USA, GDP decreased by 3.5\% compared to the previous year. Due to the economic blockade and in the absence of shortterm work programmes, the unemployment rate rose significantly. Exports registered an important decrease in some periods of the previous year. Moreover, corporate investment and industrial production suffered a significant decline. In this context, the US Federal Reserve (FED) lowered even more its benchmark interest rates in 2020. Although China was the only economy to expand in 2020, its growth rate of $2.3 \%$ significantly decreased compared to the previous year. Consumer demand almost completely collapsed during the lockdown of last spring. In spite all these, the demand strongly increased at the beginning of the summer and lasted through to the end of the year, thus helping the economy to recover. Japan, an export-reliant country, also suffered a considerable decline of economic production $(-5.3 \%)$ due to the coronavirus pandemic related to the analysed period. The main factors were lower private consumption and the drop of exports.

After one of the most difficult years, global automotive industry tries to recover, the consumers coming back in showrooms, after the restrictions imposed during the pandemic, as it is shown in an analysis conducted by Bloomberg.

Comparison of BMW group's forecasts compared to the results of year 2020 
Thus the table below presents the key performance indicators for developing the BMW Group as a whole, as well as the segments of services in automotive sector, motorcycles and the analysis of acquired financial services. Within the context of the crisis generated by COVID-19 pandemic, in the first quarter of 2020, BMW Group partially revised their perspectives for this year, and the changes are presented as it follows. Detailed information on the Group's key performance indicators is presented in conjunction with the analysis of the Group's results of operations:

Table 1 Results of operations of the BMW Group

\begin{tabular}{|c|c|c|c|}
\hline *in $€$ million & 2020 & 2019 & Change in \% \\
\hline Revenues & 98,990 & 104,210 & -5.0 \\
\hline Cost of sales & $-85,408$ & $-86,147$ & -24.8 \\
\hline Gross profit & 13,582 & 18,063 & 6.1 \\
\hline Selling and administrative expenses & $-8,795$ & $-9,367$ & - \\
\hline Other operating income and expenses & 43 & $-1,285$ & -34.8 \\
\hline Profit before financial result & 4,830 & 7,411 & - \\
\hline Financial result & 392 & -293 & -26.6 \\
\hline Profit/loss before tax & 5,222 & 7,118 & 36.2 \\
\hline Income taxes & $-1,365$ & $-2,140$ & -22.5 \\
\hline Profit from continuing operations & 3,857 & 4,978 & - \\
\hline Profit/loss from discontinued operations & - & 44 & -23.2 \\
\hline Net profit & 3,857 & 5,022 & -23.3 \\
\hline Earnings per share (preferred stock in $€$ ) & 5.73 & 7.47 & -23.2 \\
\hline
\end{tabular}

Source: www.bmwgroup.com/en.html

Specific analysis. Because of covid-19 pandemic, bmw Group revenues for the financial year under report were moderately down compared to the previous year. Negative currency effects caused by the unfavorable development of the US dollar, Russian rouble and Chinese currency also had a significant impact on incomes. It can be noticed a decrease of the net profit in 2020 compared to 2019 with a value of $€ 1,165$ million due to the coronavirus pandemic. The financial result in 2020 was positive compared to the previous year.

Table 2 BMW Group revenues by regions

\begin{tabular}{|c|c|c|}
\hline in \% & 2020 & 2019 \\
\hline Europe & 44.3 & 44.4 \\
\hline Asia & 32.1 & 30.6 \\
\hline Americas & 21.4 & 22.7 \\
\hline Other regions & 2.2 & 2.3 \\
\hline Group & 100.0 & 100.0 \\
\hline
\end{tabular}

Source: www.bmwgroup.com/en.html

Specific analysis. The generating factors included product mix effects due to the less pronounced drop in the sale of vehicles, which generated high revenues, as well as a 
portfolio-related upturn in leasing revenues. Positive development on pre-owned vehicle markets were reflected in higher revenues generated from the sale of returned lease vehicles, particularly in the third and fourth quarters of the year 2020.

Table 3 The cost of sales registered by BMW Group

\begin{tabular}{|c|c|c|c|}
\hline *in $€$ million & 2020 & 2019 & Change in \% \\
\hline Manufacturing costs & 46,878 & 48,776 & -3.9 \\
\hline Cost of sales relating to financial services business & 27,114 & 25,828 & 5.0 \\
\hline Interest expense relating to financial services business & 1,960 & 2,288 & -14.3 \\
\hline Research and development expenses & 5,689 & 5,952 & 4.4 \\
\hline Amortisation of capitalised development costs & 1,710 & 1,667 & 2.6 \\
\hline Service contracts, telematics and roadside assistance & 1,411 & 1,641 & -14.0 \\
\hline Warranty expenses & 2,971 & 2,566 & 15.8 \\
\hline Other cost of sales & 1,345 & 1,384 & -2.8 \\
\hline Cost of sales & 85,408 & 86,147 & -0.9 \\
\hline
\end{tabular}

Source: www.bmwgroup.com/en.html

Specific analysis. As it can be easily noticed in the situation previously presented, BMW Group cost of sales in the year 2020 amounted to $€$ 85,408 million. Thus, higher risk-provisioning expenses, mainly arising in connection with the measurement of credit and residual value risks, were partially offset by reduced manufacturing costs due to lower production volumes. Cost of sales relating to Financial Services business went up as a result of the costs associated with the sale of returned lease vehicles, mirroring the impact on revenues. Furthermore, research and development expenses were slightly lower than in the previous year. By contrast, the amount assigned to amortisation of capitalised development costs increased in the analysed financial year. Depreciation and amortisation of tangible assets, equipment and intangible assets totalled $€$ 6,143 million. Selling and administrative expenses decreased year-on-year, influenced in particular by lower personnel expenses and a decrease in expenses for marketing and communication. Fixed cost management also contributed to a great extent to the reduction in selling and administrative expenses.

Table 4 BMW Group research and development expenditure

\begin{tabular}{|c|c|c|}
\hline$*$ in $€$ million & 2020 & 2019 \\
\hline Research and development expenses & 5,689 & 5,952 \\
\hline Amortisation & $-1,710$ & $-1,667$ \\
\hline New expenditure for capitalised development costs & 2,300 & 2,134 \\
\hline Total research and development expenditure & 6,279 & 6,419 \\
\hline
\end{tabular}

Source: www.bmwgroup.com/en.html

Specific analysis. The net amount of other operating income and expenses significantly improved, registering an important annual increase which was attributable to the expense recognised in the first half of the previous financial year. Thus, profit before financial result dropped to $€ 4,830$ million compared to $€ 7,411$ million in year 2019, reflecting the various negative impacts on the gross profit of BMW Group. On the other side, the financial result of BMW Group significantly improved each year. The figure reported for 2020 benefited in particular from an increase to $€ 1,212$ million, compared to $€ 918$ million, as it was registered in 2019, as a consequence of earnings generated by the Chinese joint venture BMW Brilliance Automotive Ltd., Shenyang, as well as from the 
gain of $€ 105$ million recorded by THERE HOLDING B. V. on the sale of shares in the card service provider HERE International B. V to Mitsubishi Corporation (MC), Nippon Telegraph and Telephone Corporation (NTT) during the first half of 2020. In the previous year, the financial result also included higher impairment losses recognised in connection with the strategic realignment of the YOUR NOW Group.

The profit of BMW Group before tax was of $€ 5,222$ million which was significantly lower than the one registered in the previous year, in value of $€ 7,118$ million. Income tax expense for the year 2020 decreased to $€ 1,365$ million, compared to the level of 2,140 million EUR, in the year 2019, mainly due to the fact that the incomes of BMW Group decreased as a consequence of COVID-19 pandemic. The effective tax rate decreased to $26.1 \%$ in 2020 , compared to the year 2019, when it was of $30.1 \%$. In the previous financial year, the effective tax rate was raised due to the non-deductibility of items for tax purposes, namely the recognition of the provision relating to the EU Commission's anti-trust proceedings and losses generated from decreasing the shares at YOUR NOW Group. The size of workforce at BMW Group slightly decreased to 120,726 employees in 2020, compared to 126,016 employees in 2019 (-4.2\%).

Table 5 Assets of BMW Group

\begin{tabular}{|c|c|c|c|}
\hline$*$ in $€$ million & 2020 & 2019 & change in \% \\
\hline ASSETS & & & 5.2 \\
\hline Intangible assets & 12,342 & 11,729 & -6.0 \\
\hline Tangible assets & 21,850 & 23,245 & -1.4 \\
\hline Leased products & 41,995 & 42,609 & 12.1 \\
\hline $\begin{array}{c}\text { Investments accounted for using the } \\
\text { equity method }\end{array}$ & 3,585 & 3,199 & 4.6 \\
\hline Other investments & & & -8.8 \\
\hline Receivables from sales financing & 84,277 & 92,437 & -9.9 \\
\hline Financial assets & 7,752 & 7,325 & -20.2 \\
\hline Deferred and current tax & 3,065 & 3,403 & -6.3 \\
\hline Other assets & 10,326 & 12,939 & -8.7 \\
\hline Inventories & 14,896 & 15,891 & 12.5 \\
\hline Trade receivables & 2,298 & 2,518 & -5.0 \\
\hline Cash and cash equivalents & 13,537 & 12,036 & 228,034 \\
\hline Total assets & 216,658 & & \\
\hline
\end{tabular}

Source: www.bmwgroup.com/en.html

Specific analysis. Adjusted for currency effects, the BMW Group's balance sheet total was slightly lower than at 31 December 2019. Tangible assets (adjusted for currency effects) were slightly down compared to the previous year, mainly due to the lower amount of capital expenditure in 2020. In the previous year, investments at the BMW plants in Spartanburg, USA and San Luis Potosí, Mexico had the effect of increasing tangible assets. Leased products (adjusted for currency effects) were slightly up compared to the previous year due to portfolio growth, mainly in Germany, Italy and Switzerland.

Receivables from sales financing (adjusted for currency effects) went down slightly compared to 31 December 2019, primarily due to the decrease in dealership financing, mainly in the USA, Germany, the UK and France. A total of 1,238,286 new credit financing contracts were concluded with retail customers during the financial year 2020. The number 
of contracts in place with dealerships and retail customers decreased by $0.6 \%$ compared to the previous year, registering at present 4,040,231 contracts.

Table 6 BMW Group equity and liabilities

\begin{tabular}{|c|c|c|c|}
\hline$*$ in $€$ million & 2020 & 2019 & Schimbare în \% \\
\hline Equity and liabilities & & & \\
\hline Equity & 61,520 & 59,907 & 2.7 \\
\hline Pension provisions & 3,693 & 3,335 & 10.7 \\
\hline Other provisions & 13,982 & 13,209 & 5.9 \\
\hline Deferred and current tax & 1,256 & 1,595 & -21.3 \\
\hline Service contracts, telematics and roadside assistance & 1,411 & 1,641 & -14.0 \\
\hline Financial liabilities & 106,376 & 116,740 & -8.9 \\
\hline Trade payables & 8,644 & 10,182 & -15.1 \\
\hline Other liabilities & 21,187 & 23,066 & -8.1 \\
\hline Total equity and liabilities & 216,658 & 228,034 & -5.0 \\
\hline
\end{tabular}

Source: www.bmwgroup.com/en.html

Specific analysis. Group equity rose slightly by $€ 1,613$ million to $€ 61,520$ million, driven primarily by the profit of $€ 3,775$ million attributable to shareholders of BMW AG. The dividend payment for the financial year 2019 amounted to $€$ 1,646 million, reducing equity accordingly. Financial liabilities decreased moderately in 2020, with repayments of maturing bonds exceeding new issues.

\section{Conclusions regarding the analysis of BMW group economic position}

From the above-mentioned information, despite the volatility caused by the outbreak of the coronavirus pandemic, the results of operations, financial position and net assets of the BMW Group remained stable throughout the financial year, thanks to a set of measures that were immediately implemented, including focused working capital management, strict investment and fixed cost management and targeted liquidity management. The value added statement shows the value of work performed by the BMW Group during the financial year, less the value of work bought in. Depreciation and amortisation, cost of materials, and other expenses are treated as bought-in costs in the value added calculation. Thus, net valued added by the BMW Group remained at a high level in the financial year 2020.

\section{Reference}

1. Dobrin G.I., (2013) - Economics and risk assessment in the business world, "Lucian Blaga" University Publishing House, Sibiu;

2. Dobrin G.I., (2014) - Analysis and evaluation of risks specific to the Romanian business environment, "Lucian Blaga" University Publishing House, Sibiu

3. Lupu, D., Maha, L. G., \& Viorică, E. D. (2020). COVID-19 Incidence in Europe: Drivers and Government Interventions. Transylvanian Review of Administrative Sciences, 16(SI), 80-93.

DOI: http://dx.doi.org/10.24193/tras.SI2020.5

4. Schmidt Timeea (2014) - The Importance, Necessity and Role of the Global Diagnosis of the Company in the Evaluation Process, Nagard Publishing House, Lugoj

5. www.bmwgroup.com/en.html

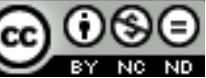

This article is an open access article distributed under the terms and conditions of the Creative Commons Attribution - Non Commercial - No Derivatives 4.0 International License. 